\title{
Basic approaches to health-saving education of schoolchildren in Ukraine and Finland
}

\author{
O. S. Karpus \\ Sumy state pedagogical university named after A. S. Makarenko, Sumy, Ukraine \\ Paper received 22.04.18; Accepted for publication 28.04.18.
}

\section{http://doi.org/10.31174/SEND-PP2018-163VI67-09}

\begin{abstract}
The article focuses on the main approaches to health-saving education of schoolchildren in secondary schools in Ukraine and Finland. The purpose and peculiarities of the process of health-saving education in the Finnish and Ukrainian schools are determined. Human health is the basic value of the individual. Strong health of the younger generation is a guarantee of successful development of the entire nation. The importance of health-saving education at school has been proven over the last decade. Strengthening and preserving the health of young people continue to gain momentum. The article attempts to compare the basic approaches to health-saving education in Ukraine and Finland.
\end{abstract}

Keywords: health-saving education, health, approaches to health-saving activity, healthy lifestyle, schoolchildren's health, health culture.

Introduction. Modern society is in a rapid development. The issue of public health is becoming a state priority when it comes to children, adolescents and youth. The health of the individual depends largely on the attitude of the person to himself. The most favorable period for the formation of useful habits and skills is the school period. At this time, the child is open to learning new experiences and forming a positive attitude towards themselves and their own health. That is why in Ukraine and other European countries, such as Finland, world trends are being introduced to improve schoolchildren's health through education. The potential of the educational process in secondary schools is very powerful. Due to the introduction of health-saving activities in education, students form a valuable attitude towards their own health and health culture.

A brief overview of publications on the topic. The state of human health is an important complex indicator, which depends on a large number of factors, the impact of socio-economic and environmental conditions of existence [14]. According to the results of various studies, there is an increase in the number of somatic diseases, physical defects and other functional disorders in the world. Strengthening the health of the population, promoting dissemination of health information, preserving nature and introducing health-saving technologies in school education have become the key to the development of the health care system at the world level. Recently, health-saving education has become popular all over the world. However, the actual approaches to health-saving education in Ukraine and Finland are somewhat different.

The complexity of the phenomenon of health preservation attracts attention of many native and foreign researchers. Among contemporary native researchers, health-saving education has become the subject of special interest of: T. Boichenko, A. Besiedina, I. Mordvinova, O. Ezhova and others. Health-saving activity in Finland was studied by the following scientists: J. Teperi, L. Vuorenkoski, O. Kontula and others. The issue of healthsaving education remains the subject of many scientific investigations by such researchers as M. Bezruky, M. Lukianchenko, V. Horashchuk and others.

The aim of the article is to analyze the main approaches to health-saving education of students and identify the need for healthcare work with students in Ukraine and Finland.
Materials and methods. For achieving the aim of the article, we have used theoretical methods of research: analysis and synthesis of scientific literature and information sources of health-saving topics for clarification of the main categories of research; comparative-pedagogical for studying foreign experience.

In order to define the meaning of the concepts of "approaches to health preservation", "health-saving education of schoolchildren", "healthy lifestyle", an analysis of research works by J. Komensky, N. Bashavets, O. Vashchenko, T. Shapovalova , T. Andriushchenko, J. Teperi, L. Vuorenkoski, O. Kontula is conducted.

Results and discussion. In modern cpnditions, the concept of "health" has a multifunctional content. At the present stage of development of a society, a healthy person is the person who builds his own health independently: effectively copes with stressful situations, prevents conflicts and solves them, is able to make the right decisions, realizes his own place in the world and is able to improve his health and the environment [14].

In his time, Jan Amos Komensky paid much attention to preserving health of children and youth; he advised to use the life purposefully for the proper organization of a healthy future. The researcher singled out three basic conditions for health promotion:

- simple meals in a moderate amount;

- the right approach to work and rest;

- intensive physical exercises [7].

Before highlighting the peculiarities of the process of health-saving education we consider it expedient to focus on the basic conceps of our study.

Healthy lifestyle is a certain way of human life, which involves formation, strengthening and preservation of health []. Formation of a healthy lifestyle in schoolchildren is a complex process built on the basis of interdisciplinary relationships. In formation of a healthy lifestyle are involved the following sciences: valeology, physiology, pedagogy, psychology, sociology, medicine, etc.

Health-saving education - the interaction of the teacher and the student in the educational process, which ensures mental, physical and social well-being of each participant of the process. For realization of health-saving education it is necessary to ensure a health-saving environment.

Healthcare-saving environment is an environment favorable for life, work, rest and any other human activities, 
favourable social, spiritual and material conditions that have a positive impact on human health. For realization of health-saving education and organization of health-saving environment there are certain approaches and techniques [5].

Let us turn to vocabulary sources, where the concept of "approach" is regarded as "a set of methods of considering something, the influence on someone, something, attitude towards someone, something" [12].

At the initiative of WHO in 1995, the Global Initiative for the Establishment of Schools of Health was introduced as one of the methods for organizing health-care activities in the European space. This program aims to promote the development of a healthy lifestyle among schoolchildren and young people, to strengthen health and introduce health-saving education at different levels: local, national, global. In WHO, health-saving education is defined as "a combination of established learning experiences to help people improve their health through knowledge deepening or through their impact on their health" [10].

Schools of health are aimed at strengthening their own potential as a health-saving environment for life, training and work. As the main approach to ensuring health-saving education the school of health is aimed at:

- productive education for health formation;

- providing adequate opportunities for physical education and rest;

- provision of school sanitary and medical services;

- healthy nutrition programs and food safety;

- projects for the promotion of a healthy lifestyle;

- projects of social and psychological support and counseling on these problems;

- improving the health of school staff, students and their families;

- working with community leaders to understand what affects the health and education of the child adversely [11].

Ukraine and Finland are direct participants of the Global Initiative for the Establishment of Schools of Health Program and have introduced schools of health in their countries. Health-saving education in Ukraine is implemented through the following principles:

- do not hurt;

- caring for the student's and teacher's health;

- continuity of training;

- interdisciplinary approach to learning;

- responsibility for own health;

- high activity;

- correspondence of the organization and the content of education to the student's age [4].

Analyzing the approaches to health-saving education of schoolchildren in Ukrainian schools, we have highlighted the main points that ensure successful formation of a health-saving educational process:

1) reasonable organization of the school day regime;

2) favorable health-saving environment;

3) strict compliance with the sanitary norms of the institution;

4) organization of healthy eating;

5) disease prevention, vaccination and timely hospitalization of students;

6) physical activity [4].

Finland is one of the leading countries in education in general and health-saving education in particular. In Finn- ish "Schools for health promotion" there are the following approaches to health-saving education:

- taking care of yourself and others;

- prevention of the main causes of illness, disability, mortality (alcoholism, drug addiction, helminths, smoking, AIDS, violence, malnutrition, injuries, sedentary lifestyles);

- creation of a health-saving environment through medical services, political situation in the country, physical and social conditions;

- influence on schoolchildren's behavior, which is related to the influence on health (attitude, values, knowledge, skills, support), etc. [8].

School health-saving education in Finnish schools is constructed very responsibly. In order to implement certain approaches and techniques it is organized:

1) creation of tools for the dissemination of information about healthcare system;

2) exchange of experience with other countries and regions;

3) identifying problems and controversies that require the greatest attention;

4) studying the problem of financing and providing medical services [9].

We see that approaches to health-saving education in Ukraine and Finland are different. The implementation of these techniques requires a solution to the issue of healthsaving competence.

Health-saving competence is the ability of a person to maintain physical, mental, spiritual and social health [2]. In the works of T. Shapovalova, health-saving competence is defined as a flexible dynamic personality trait, manifested in the ability of a person to develop his own scheme of a healthy life and to manage such a process. Personality should be able to direct activities at the preservation of health, to adequately assess their behavior and behavior of others [15].

In studies of $\mathrm{O}$. Vashchenko health-saving competence is defined as a set of knowledge, skills, values and attitudes aimed at organization, strengthening and preservation of health [6]. N. Bashavets health-saving competence defines as the ability to engage in health-saving activities at a high level. This person is distinguished by deep knowledge in the field of healthcare [3].

T. Andriushchenko interprets health-saving competence as the need to give children knowledge about health, formation of a value-oriented attitude towards their own health and all living creatures, creating a health-saving environment. All these items create a solid foundation for a healthy lifestyle [2].

Conclusions. So, we have found out that a developed society has the following features: presence of a high level of education and constant development of a health culture. It is logical that high educational level of the social environment is closely linked to high health indicators. The tasks of strengthening and preserving the health of the person and the whole nation need to be addressed with the help of pedagogical means. The basic approaches, methods, techniques and skills for the development of health-saving skills of students in the context of school education are complex. The main approaches to healthsaving activities in Ukraine and in Finland are different, but in one way or another they are aimed at improving the health of each person and nation as a whole. 


\section{REFERENCES IN ORIGINAL LANGUAGE}

1. Ahonen, R., Martikainen, J. Lääkevaihdon ensimmäinen vuosi. Helsinki, Kela Sosiaali - ja terveysturvan katsauksia, $2005,68$.

2. Андрющенко, Т. К. Формування здоров'язбережувальної компетентності як соціально-педагогічна проблема // Науковий вісник Волинського національного університету імені Лесі Українки, 2012, 7, С. 123-127.

3. Башавець, Н. А. Здоров'язбережувальна компетентність майбутнього фахівця як основа його культури // Наука i освіта, 2013, 1-2, С. 120-121.

4. Біленко, О. Школа сприяння здоров'ю - імідж сучасного навчального закладу // Початкова школа, 2013, 8, С. 48.

5. Вайнер, Е. Н. Формування здоров'язберігаючого середовища в системі загальної освіти // Валеологія, 2004, 1, C. 21-26.

6. Ващенко, О. М., Срмолова, В. М., Іванова, Л. І. та ін. Фізкультурно-оздоровчі заходи в режимі навчального дня молодшого школяра. Кам'янець-Подільський: Абетка, $2012,192 \mathrm{c}$.

7. Коменский, Я. А. Избранные педагогические сочинения: в 2 т. Т. 1. М.: Педагогіка, 1982, 656 с. - (Педагогическая библиотека).

8. Puska, P. Proekt «Severnaya Kareliya»: ot Severnoy Karelii do proekta natsional'nogo masshtaba, Helsinki: Publishing house of the University of Helsinki, 2011, 291 p.

9. Vuorenkoski, L. Finland: Health System Review, 2008, 195.

10. WHO Global school health initiative. World Health Organization. Retrieved from: http://www.who.int/school_youth_health/gshi/en/.

11. WHO School and youth health. What is a health promoting school? Retrieved from: http://www.who.int/school_youth_health/gshi/hps/en/.

12. Академічний тлумачний словник (1970-1980). Словник української мови. Режим доступу: http://sum.in.ua/s/pidkhid

13. Про затвердження Державного стандарту базової i повної загальної середньої освіти від 23 листопада 2011 p. № 1392 . Режим доступу: http://zakon2.rada.gov.ua/laws/show/1392-2011-\%D0\%BF

14. Редько, Т. М. Здоров'ярозвивальні технології в процесі фізичного виховання студентів педагогічних університетів // Вісник Чернігівського національного педагогічного університету, 2015, С. 45-48. Чернігів, ЧНПУ.

15. Шаповалова, Т. Г. Формування здоров'язбережувальної компетентності гуртківців у позашкільному навчальному закладі. Педагогічні науки: теорія, історія, інноваційні технології, 2012, 2 (20), С. 191-199.

\section{REFERENCES}

2. Andriushchenko, T. K. Formation of health-saving competence as a socio-pedagogical problem // Scientific Bulletin of the Volyn National University named after Lesia Ukrainka, 2012, 7, P. 123-127.

3. Bashavets, N. A. Health-saving competence of the future specialist as the basis of his culture // Science and Education, 2013, 1-2, P. 120-121.

4. Bilenko, O. The School of Health Promotion - The Image of a Modern Educational Institution // Primary School, 2013, 8, P. 48.

5. Weiner, E. N. Formation of health-saving environment in the system of general education // Valeologiya, 2004, 1, P. 21-26.

6. Vashchenko, O. M., Yermolova, V. M., Ivanova, L. I. and others. Physical-and-health measures in the mode of the school day of the junior schoolchild. Kamianets-Podilsky: Abetka, 2012, 192 p.

7. Komensky, J. A. Selected pedagogical works: in 2 vol. Vol. 1. M.: Pedagogy, 1982, 656 p. - (Pedagogical Library).

12. Academic Explanatory Dictionary (1970-1980). Dictionary of the Ukrainian language. Retrieved from: http://sum.in.ua/s/pidkhid

13. On approval of the State standard of basic and complete secondary education from November 23, 2011 № 1392. Retrieved from: http://zakon2.rada.gov.ua/laws/show/13922011-\%D0\%BF

14. Redko, T. M. Health developing technologies in the process of physical education of students of pedagogical universities // Bulletin of Chernihiv National Pedagogical University, 2015, P. 45-48. Chernihiv.

15. Shapovalova, T. H. Formation of the health-saving competence of the circles members in an out-of-school education institution. Pedagogical sciences: theory, history, innovative technologies, 2012, 2 (20), P. 191-199.

\section{Основные подходы к здоровьесберегательному воспитанию школьников в Украине и Финляндии}

\section{О. С. Карпусь}

Аннотация. В статье уделяется внимание основным подходам к здоровьесберегательному воспитанию школьников в средних школах Украины и Финляндии. Определены цель и особенности процесса оздоровительного образования в финских и украинских школах. Здоровье человека является основной ценностью личности. Крепкое здоровье молодого поколения является гарантией успешного развития всей нации. За последнее десятилетие была доказана важность здоровьесберегательного образования в школе. Укрепление и сохранение здоровья молодых людей продолжают набирать актуальность. В статье предпринята попытка сравнить основные подходы к здоровьесберегательному образованию в Украине и Финляндии.

Ключевые слова: здоровьесберегательное воспитание, здоровье, подходы к здоровьесберегательной деятельности, здоровый образ жизни, здоровье школьников, культура здоровья. 